\title{
Effect of Organic Mulching on Soil Moisture, Yield, and Yield Contributing Components of Sesame (Sesamum indicum L.)
}

\author{
Goitom Teame, ${ }^{1}$ Alemtsahay Tsegay, ${ }^{2}$ and Berhanu Abrha ${ }^{2}$ \\ ${ }^{1}$ Crop Research Core Process, Humera Agricultural Research Center, Tigray Agricultural Research Institute, Humera, Ethiopia \\ ${ }^{2}$ Department of Dryland Crops and Horticultural Science, Mekelle University, Mekelle, Ethiopia \\ Correspondence should be addressed to Goitom Teame; goitomyafenan@gmail.com
}

Received 6 January 2017; Revised 24 March 2017; Accepted 23 April 2017; Published 8 June 2017

Academic Editor: Manuel Tejada

Copyright (c) 2017 Goitom Teame et al. This is an open access article distributed under the Creative Commons Attribution License, which permits unrestricted use, distribution, and reproduction in any medium, provided the original work is properly cited.

\begin{abstract}
Sesame (Sesamum indicum L.) is one of the chief foreign exchange earning oil crops in Ethiopia. However, its productivity remains low due to lack of appropriate agronomic practices. The aim of this research was to study the effect of organic mulches on sesame productivity and in situ moisture conservation. This experiment was carried out in Humera Agricultural Research Center, Western Tigray, during 2015 growing season. The experimental design was Randomized Complete Block Design with three replications. There were four types of organic mulches; rice straw, sorghum straw, sesame straw, and Sudan grass were compared with control. Sesame, variety Setit- 1 was used in the experiment. The organic mulching rate of application was 10 ton ha ${ }^{-1}$ and this was applied evenly to the soil immediately after germination. Soil water content, phonological characteristics yield, and yield components of sesame were collected. The analyzed results indicated that organic mulching had significant effect on soil moisture content at $0-0.2 \mathrm{~m}, 0.21-0.4 \mathrm{~m}$, and $0.41-0.6 \mathrm{~m}$ in every two-week interval after sowing and grain yield of sesame. Sesame straw conserved highest soil moisture content as compared with respective mulch material. The highest yield $\left(664 \mathrm{~kg} \mathrm{ha}^{-1}\right)$ was recorded with Sudan grass while the lowest grain yield $\left(190 \mathrm{~kg} \mathrm{ha}^{-1}\right)$ was recorded with no mulch.
\end{abstract}

\section{Introduction}

Sesame (Sesamum indicum L.) is an industrial crop that belongs to the Pedaliaceae family. It grows chiefly for its vital seed that contains about $50 \%$ oil and $25 \%$ protein [1]. Despite its importance as source of cooking oil and foreign currency earning, sesame productivity is very low especially in dry land area like in Tigray. This is dominantly due to moisture stress and weed infestation which can cause a yield falling of up to $86.3 \%$ in sesame [2]. Similarly sesame yield is severely affected by a biotic factor such as drought stress [3]. In relation to this, it was reported that sesame growth and development as other crops is highly affected by water stress [4]. Studies revealed that oleic acid which is one of the major characteristics of sesame oil decreased with different levels of water deficit. Inefficient utilization of water due to improper field and crop management practices is another bottle neck for sesame and other crops' production in dry lands. In addition to water stress problem the effect of weed takes a lion share in sesame production.
Mulch has a great role in soil moisture conservation through modification of microclimatic soil conditions. It helps to prevent weed growth, reduce evaporation, and increase infiltration of rain water during growing season [5]. Research results have shown that mulch provides numerous benefits to crop production by improving the physical, chemical, and biological soil properties [6]. Different research result showed mulch increase soil moisture through increasing infiltration, reducing evaporation, and modifying water retention capacity of the soil $[7,8]$. Adeoye [9] reported high soil moisture content up to a depth of $60 \mathrm{~cm}$ in grassmulched soil. On the other hand water holding capacity of the soil improved through mulch decomposition and humus formation [8].

In aqua crop water productivity model by Raes et al. [10], soil evaporation reduction by $50 \%$ was modeled with 100 percent cover of the soil by organic mulch. This is in line with Hatfield et al. [11] who also reported a 34-50 percent reduction in soil water evaporation as a result of crop residue mulching. 
TABLE 1: Soil characteristics of the experimental site (presowing).

\begin{tabular}{|c|c|c|c|c|}
\hline \multirow[t]{4}{*}{ Location } & & & Humera & Remark \\
\hline & \multirow{3}{*}{ Texture } & Clay (\%) & 68 & \multirow[t]{3}{*}{ Clay } \\
\hline & & Silt (\%) & 13 & \\
\hline & & Sand (\%) & 19 & \\
\hline \multirow{7}{*}{ Soil characteristics } & Total-N & & 0.04 & \multirow[t]{5}{*}{ Low } \\
\hline & P ppm & & 2.78 & \\
\hline & $\mathrm{K}$ ppm & & 62.8 & \\
\hline & OM \% & & 0.98 & \\
\hline & $\mathrm{CEC} \mathrm{m}$ & & 30 & \\
\hline & PH Wat & & 8.45 & Basic \\
\hline & EC Wat & & 0.16 & Nonsaline \\
\hline
\end{tabular}

Mekelle Soil Laboratory, 2016.

Different types of organic mulches have been used to obtain good crop growth and yield in crops like ground nut [12]; soybean [13]; sesame [14]; sunflower [15]; and sweet pepper [16]. The purpose of this research is to determine the role of organic mulching on soil moisture conservation and sesame productivity.

\section{Material and Method}

2.1. Experiment Location. The field experiment was conducted in 2015 main growing season in Humera Agricultural Research Center Western zone of Tigray Ethiopia. It is situated between $13^{\circ} 14^{\prime}$ to $14^{\circ} 27^{\prime} \mathrm{N}$ and $36^{\circ} 27^{\prime}$ to $37^{\circ} 32^{\prime} \mathrm{E}$ and about $600 \mathrm{~km}$ from Mekelle capital city of Tigray regional state. The dominant soil type of the area is chromic vertisol (Table 1).

2.2. Experimental Design and Treatment. The experimental design used was Randomized Complete Block Design (RCBD) with three replications and five treatments. Those treatments were sesame straw, sorghum straw, rice straw, Sudan grass, and no mulch. The gross plot size was $6 \mathrm{~m}^{2}$ and the net plot size was $3.6 \mathrm{~m}^{2}$. The distance between the plot and block was 1 and $1.5 \mathrm{~m}$, respectively. Sesame seed variety Setit-1 was sown at row to row and plant to plant distance of $40 \mathrm{~cm}$ and $10 \mathrm{~cm}$, respectively. The field was tilled and supplied with $100 \mathrm{~kg}$ of NPS $\left(19 \mathrm{~N}-38 \mathrm{P}_{2} \mathrm{O}_{5}+7 \mathrm{~S}\right)$ and $50 \mathrm{~kg}$ of urea fertilizer. The urea was applied in split form $25 \mathrm{~kg}$ at sowing and 25 at flower initiation. In accordance with the methods adopted by Ramakrishna [17] and Aminu-Taiwo [18] the rate of mulches used was $6 \mathrm{~kg}$ per plot which is equivalent to 10 ton/ha and was applied at row whole immediately after germination evenly.

\subsection{Measurements and Measurements Method}

2.3.1. Soil Moisture Content. Soil moisture content was determined by taking fresh soil sampled from depths of $0-0.2 \mathrm{~m}$, $0.21-0.4 \mathrm{~m}$, and $0.41-0.6 \mathrm{~m}$ in the experimental field every two weeks. Sampled fresh weight was weighed and dried in oven for 24 hours at $105^{\circ} \mathrm{C}$. The gravimetric soil water content was determined using (1) after weighing oven dried soil sample

Soil moisture content (\%)

$$
=\frac{\text { fresh soil weight }- \text { dry soil weight }}{\text { dry soil weight }} \times 100 \text {. }
$$

2.3.2. Phenology and Agronomic Trait of Sesame. Each phonological stage was determined by visual observation. Moreover number of capsules per plant and number of seeds per capsule were counted from five randomly selected plants per plot. Plant height is one of the growth parameters that was measured from five plants per plot. To determine the number of seeds per capsule, the seeds of three capsules (lower, medium, and uppermost position on the plant) from each of five plants were counted. Thousand-seed weight was determined by counting 1000 seeds from each plot after sun drying. Seed yield of each plot was weighed in grams and converted to area basis to determine the yield $\mathrm{kg} / \mathrm{ha}$.

2.4. Data Analysis. The data collected from each experimental plot were subjected to analysis using appropriate software (GenStat 15 (64 bits)) [19]. Treatments that show significant differences were subjected to mean comparison test, Duncan multiple range test (DMRT).

\section{Result and Discussion}

\subsection{Effect of Mulching on SMC at Different Soil Depth and Growth Phases}

3.1.1. Effect of Mulching on SMC during 15 DAS. Organic mulching had highly significant difference $(p<0.001)$ on soil moisture content in all soil depths during 15 days after sowing. In the upper soil depth (0-0.2 m) among the mulching treatments sesame and sorghum had statistically similar soil moisture result so do Sudan grass and rice mulches. The highest soil moisture (30\%) was conserved under sesame mulch while the lowest soil moisture content $(26.3 \%)$ was conserved under Sudan grass (Table 2). In the medium soil depth $(0.21-0.4 \mathrm{~m})$ also sesame and Sudan grass 


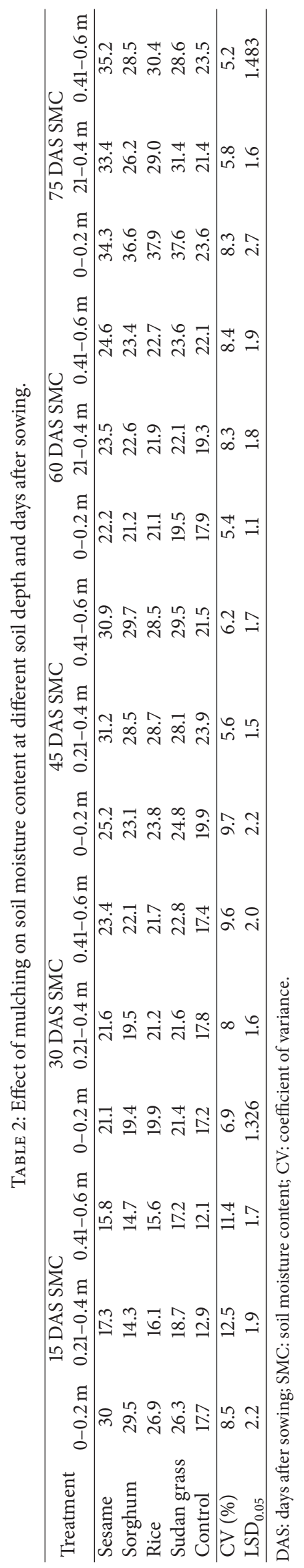


(18.7 and $17.3 \%)$ were conserved highest soil moisture content while the lowest (16.1 and 14.3\%) was conserved under rice and sorghum mulching material, respectively (Table 2). Moreover, in the lower soil depth $(0.41-0.6 \mathrm{~m})$ the highest soil moisture was conserved in all mulching material except sorghum. Generally all mulching material showed significant soil moisture conservation than no mulch plot. This growth stage of the crop is known as vegetative (seedling) according to [20]. The conserved moisture due to mulch treatments had a positive role in sesame seedling as compared to no mulch plots which had shown symptoms of water stress such as wilting and leaf rolling. This result is in line with da Silva et al. [21] who reported that germination and start of vegetative growth are more sensitive to water stress in sesame.

3.1.2. Effect of Mulching on SMC during 30 DAS. Soil moisture content was influenced $(p<0.001)$ by mulching treatment in all soil depth during 30 days after sowing. In the upper soil depth $(0-0.2 \mathrm{~m})$ the highest soil moisture (21.4 and $21.1 \%$ ) was conserved by Sudan grass and sesame while the lowest (19.9 and 19.4\%) was conserved by rice and sorghum correspondingly (Table 2 ). All mulching treatment conserved similar soil moisture content excluding sorghum in the medium soil depth $(0.21-0.4 \mathrm{~m})$. On the other hand all mulching material conserved similar amount soil moisture in the lower soil depth $(0.41-0.6 \mathrm{~m})$. This growth period is known as vegetative in sesame (juvenile and prereproductive) [20]. The soil moisture conserved by the mulching treatment was vital for number of leaves, plant height, and other growth parameters whereas the lowest soil moisture conserved by bare plots was responsible for poor growth performance. This result is in line with da Silva et al. [21] who reported that germination and start of vegetative growth are more sensitive to water stress in sesame.

3.1.3. Effect of Mulching on SMC during 45 DAS. The analysis of variance revealed that mulching treatment was highly influenced $(p<0.001)$ on soil moisture content in all depth throughout 45 days after sowing. All mulching material had similarly highest moisture conservation whereas the no mulch treatment had conserved the lowest in the upper depth $(0-0.2 \mathrm{~m})$. In the medium soil depth $(0.21-0.4 \mathrm{~m})$ the highest soil moisture was conserved under sesame mulch plots while the lowest was conserved under sorghum, rice, and Sudan grass. On the contrary all mulching treatment had similar moisture conservation ability except rice in the lower soil depth $(0.41-0.6 \mathrm{~m})$. This period of sesame growth is called prereproductive (50\% flowering) by [20]. All mulching treatment conserved nearly the same amount of water that enables them to convert their produced flower to capsule while the stressed treatment exhibited flower abortion and poor capsule formation (gab between nodes). This result is in line with Langham [20] who reported moisture stressed sesame plant did not form auxiliary flowers.

3.1.4. Effect of Mulching on SMC during 60 DAS. Soil moisture content was highly influenced $(p<0.001)$ due to mulch treatment in all depth during 60 days after sowing. There was no soil moisture variation among mulching treatment in all three depths except that of bare soil (no mulch). This period of growth in sesame is called reproductive stage by [20]. The mulch treated plots produce highest plant height with capsule (without gab) while the stressed plots produce the shortest plant height and lowest capsule formation in relation to moisture conserved.

3.1.5. Effect of Mulching on SMC during 75 DAS. The analysis of variance revealed that soil moisture content highly is influenced by mulching treatment in all soil depth during 75 days after sowing. In the upper soil depth $(0-0.2 \mathrm{~m})$ the highest soil moisture $(37.9,37.6$, and $36.6 \%)$ was conserved in all mulching while the lowest soil moisture (34.3\%) was conserved in sesame mulch plots (Table 2). In the medium soil depth the highest soil moisture content was under sesame and followed by Sudan grass while the lowest soil moisture content was conserved under rice. In the lower soil depth $(0.41-0.6 \mathrm{~m})$ the highest soil moisture content was conserved under sesame and followed by rice straw while the lowest soil moisture content was conserved under Sudan grass and sorghum straw. The soil moisture conserved by mulching treatment had important role in grain filling as compared to no mulch treatment.

\subsection{Effect of Mulching on Phenology and Agronomic Trait of Sesame}

3.2.1. Days to $50 \%$ Flowering. The current finding did not show significant effect $(p>0.05)$ of organic mulching on $50 \%$ flowering. However, no mulch plots flowered earlier than mulch plots. This could be due to weed suppression and moisture conservation ability that let mulched plot delay flowering. This is in line with Van Donk et al. [22] who reported a delay flowering with the application of different level of mulch as compared to no mulch. On the contrary Komla [16] reported insignificant effect of mulching on $50 \%$ flowering in the dry condition.

3.2.2. Days to $90 \%$ Maturity. The present result revealed that all mulching materials showed insignificance influence on maturity except sesame mulching ( $p<0.05$ ). The longest period taken for maturity (94 days) was recorded under sesame straw and the lowest period was recorded in no mulch plots (90 days) (Table 3). Mulch material had an influence on reducing environmental stress such as water stress by conserving moisture that serves for the plant to facilitate growth and development.

3.2.3. Plant Height $(\mathrm{cm})$. Mulching in this study showed significant difference $(p<0.05)$ on plant height. The maximum plant height $(84 \mathrm{~cm})$ was measured under sesame straw mulch; even it is statistically did not differ under Sudan's grass and sorghum straw, whereas the lowest $(54 \mathrm{~cm})$ was scored under no mulch (Table 3 ). The highest plant height recorded for sesame straw, Sudan's grass, and rice mulches could be due to better soil water content that was conserved. This conserved moisture was essential for nutrient transporting, 
TABLE 3: Effect of mulching organic mulching on phenology, yield, and yield component of sesame.

\begin{tabular}{|c|c|c|c|c|c|c|c|}
\hline \multirow{2}{*}{ Mulch } & \multicolumn{7}{|c|}{ Treatments } \\
\hline & $\mathrm{DF}$ & $\mathrm{DM}$ & $\mathrm{PH}$ & NCP & NSPC & TSW & GY (kg/ha) \\
\hline Sudan grass & 40.0 & 92.9 & 83.0 & 37.5 & 40.0 & 3.8 & 664.0 \\
\hline Sesame straw & 40.0 & 93.9 & 85.0 & 35.4 & 43.0 & 3.5 & 525 \\
\hline Sorghum straw & 41.0 & 92.4 & 79.0 & 36.3 & 45.0 & 3.4 & 520 \\
\hline Rice straw & 41.0 & 92.2 & 74.0 & 26.3 & 39.0 & 3.2 & 470 \\
\hline Control & 38.0 & 90.4 & 54.0 & 22.8 & 34.0 & 3.2 & 190 \\
\hline $\mathrm{CV}(\%)$ & 7.0 & 1.2 & 4.5 & 14.7 & 6.1 & 5.4 & 7.6 \\
\hline LSD 0.05 & 2.7 & 1.1 & 1.6 & 6.3 & 2.4 & 0.2 & 35.3 \\
\hline
\end{tabular}

$\mathrm{DF}=$ days to $50 \%$ flowering, $\mathrm{DM}=$ days to $90 \%$ maturity, $\mathrm{PH}=$ plant height $(\mathrm{cm}), \mathrm{BR}=$ number of branches per plant, $\mathrm{NCP}=$ number of capsules per plant, $\mathrm{NSPC}=$ number of seeds per capsule, TSW $=$ thousand-seed weight $(\mathrm{g})$, and GY $=$ grain yield.

translocation of assimilate, cell division, and cell differentiation. So plants that grow on mulch treatment had enough soil moisture to support the plant growth while plants that grow under no mulch were suffered from moisture stress and become shorter. This result is in line with Amoghein et al. [15] who noted tallest plant height in sunflower mulched with rye than no mulch plot. In addition, Ozkan and Kulak [4] reported maximum $(52 \mathrm{~cm})$ and minimum sesame plant height $(30 \mathrm{~cm})$ at soil water content of field capacity (FC) and 0.25 of FC, respectively.

3.2.4. Number of Capsules per Plant. All mulching treatment statistically had nearly similar number of capsules per plant except for rice straw. The higher mean number of capsules per plant (38) was scored under Sudan grass mulch while the lowest (23 and 26.3) was scored under no mulch and rice straw (Table 3). This could be due to the conserved amount of water on mulched plot which was essential for biological and physiological process of the plant such as transporting of nutrient from the soil via the root and translocation of assimilate to the sink from the source. On the contrary rice straw did not convert its flower effectively to capsule like that of sesame, Sudan grass, and sorghum mulches. This finding is in line with Ajibola et al. [14] who noted that elephant grass had positive effect on sesame pod number per plant (68) as compared with no mulch (30). Similar result was reported by Langham [20]; moisture stressed sesame plants did not form auxiliary flowers that produce capsule. Rice straw mulched treatment scored 1.7 time of pods/plant as compared with no mulched plot in ground nut [17].

3.2.5. Number of Seeds per Capsule. The result showed significant effect $(p<0.05)$ of organic mulching on number of seeds per capsule. Higher number of seeds per capsule (45) was scored under sorghum straw although statistically similar with sesame straw while the lowest number seeds per capsule (34) were scored under no mulch (Table 3). The highest number of seeds per capsule recorded for sorghum and sesame could be due to more moisture conserved in the soil which consequently facilitates the translocation of assimilates from source to sink. This is in line with Ozkan and Kulak [4] who reported higher number of seeds per pod in sesame (47) under higher moisture content and the lowest
(38) scored under water deficit level of irrigation. Moreover, Kim et al. [23] reported that drought stress extremely reduced seed yield per plant in sesame.

3.2.6. Thousand-Seed Weight. The analysis of variance indicated highly significant difference $(p<0.01)$ of thousandseed weight among the mulching materials. Higher thousand-seed weight $(3.8 \mathrm{~g})$ was measured under Sudan grass and followed by sesame straw $(3.5 \mathrm{~g})$ while lowest thousandseed weight $(3.2 \mathrm{~g})$ was measured under no mulch (Table 3 ). This result is in conformity with Kang et al. [13] who found highest weight $(11 \mathrm{~g})$ from 100 soybean seed under bed land preparation with mulch while the lowest $(10.5 \mathrm{~g}$ ) was recorded under no mulch (flat sown). Ozkan and Kulak [4] recorded higher seed weight $(4 \mathrm{~g})$ at field capacity irrigation while the lowest ( $3 \mathrm{~g}$ ) was recorded at deficit irrigation in sesame. Similarly Masoud [24] noted that water stress reduced soybean seed weight from 3.3 to $3.1 \mathrm{~g}$. This variation in seed weight could be due to the role moisture conserved by those mulching material (Table 3) in the physiology of the plant such as facilitating nutrient transportation and assimilate translocation.

3.2.7. Effect of Mulching on Grain Yield. The analysis of variance showed highly significant $(p<0.01)$ difference between organic mulches for yield. Higher seed yield $\left(664 \mathrm{~kg} \mathrm{ha}^{-1}\right)$ was recorded under Sudan grass mulch followed by sesame straw and sorghum mulch plots (Table 3 ). On the other hand, the lowest yield $\left(190 \mathrm{~kg} \mathrm{ha}^{-1}\right)$ was scored under no mulch. Organic mulches conserved more soil moisture because of increased infiltration and better retention and suffocate weed growth that facilitated a better crop growth and development and resulted in higher yield. This result is in line with Ajibola [14] who observed improved sesame yield $\left(185 \mathrm{~kg} \mathrm{ha}^{-1}\right)$ in plots mulched with elephant grass while the lowest yield $\left(57 \mathrm{~kg} \mathrm{ha}^{-1}\right)$ was recorded on control. Moreover, significant yield improvement with dry grass mulch compared with no mulch was reported by [25].

\section{Conclusion}

The results of the investigation indicated that organic mulching has influence on soil moisture content at different 
stages and yield of sesame as the yield increased with mulch compared to no mulch. Sudan grass, sesame, and sorghum mulches had the higher soil moisture content at different stages, which resulted in better growth and yield of sesame.

\section{Conflicts of Interest}

The authors declare that they have no conflicts of interest.

\section{Acknowledgments}

The authors acknowledge the Tigray Agricultural Research Institute, Humera Agricultural Research Center, Mekelle University, and SBN Project for providing the financial assistance and other facilities for the completion of this study. The authors also thank the colleagues who supported them during the study.

\section{References}

[1] D. Burden, "Sesame Profile. Organic Farming 2005," cited 2014 Jan 2; Available from: http://www.darcof.dk.

[2] M. Amare, G. Woldewahid, and J. Sharma, "Sesame crops versus weeds: when is the critical period of weed control?" in Proceedings of the 9th African Crop Science, African Crop Science Society, Cape Town, South Africa, October 2009.

[3] B. Kuol, M. J. Janssens, and A. Abdalla, Breeding for Drought Tolerance in Sesame (Sesamum indicum).

[4] A. Ozkan and M. Kulak, "Effects of water stress on growth, oil yield, fatty acid composition and mineral content of Sesamum indicum," Journal of Animal and Plant Sciences, vol. 23, no. 6, pp. 1686-1690, 2013.

[5] Y.-J. Yang, R. S. Dungan, A. M. Ibekwe, C. Valenzuela-Solano, D. M. Crohn, and D. E. Crowley, "Effect of organic mulches on soil bacterial communities one year after application," Biology and Fertility of Soils, vol. 38, no. 5, pp. 273-281, 2003.

[6] A. J. Cooper, "Root temperature and plant growth; a review," Commonw Bur Hortic Plant Crops Res Rev, 1973.

[7] R. Lal, "Soil temperature, soil moisture and maize yield from mulched and unmulched tropical soils," Plant and Soil, vol. 40, no. 1, pp. 129-143, 1974.

[8] S. Ji and P. W. Unger, "Soil water accumulation under different precipitation, potential evaporation, and straw mulch conditions," Soil Science Society of America Journal, vol. 65, no. 2, pp. 442-448, 2001.

[9] K. Adeoye, "Influence of grass mulch on soil temperature, soil moisture and yield of maize and gero millet in a savanna zone soil," Samaru Journal of Agricultural Research, 1984.

[10] D. Raes, P. Steduto, T. C. Hsiao, and E. Fereres, "Aquacrop-The FAO crop model to simulate yield response to water: II. main algorithms and software description," Agronomy Journal, vol. 101, no. 3, pp. 438-447, 2009.

[11] J. L. Hatfield, T. J. Sauer, and J. H. Prueger, "Managing soils to achieve greater water use efficiency," Agronomy Journal, vol. 93, no. 2, pp. 271-280, 2001.

[12] P. De, A. K. Chakravarti, P. K. Chakraborty, and A. Chakraborty, "Study on the efficacy of some bio resources as mulch for soil moisture conservation and yield of rain fed groundnut (Arachis hypogaea)," Archives of Agronomy and Soil Science, vol. 51, no. 3, pp. 247-252, 2005.
[13] J. Kang, S. Avtar, and K. Maninder, "Studies on growth and yield of soybean (glycine max 1.) under different planting methods and fertility levels,' Indian Journal of Legume Research, vol. 35, no. 3, pp. 265-267, 2012.

[14] A. Ajibola, T. Modupeola, and A. Adenuga, "Effect of different weed control practices on growth and yield of sesame in southwest Nigeria," Journal of Biological and Chemical Research, vol. 31, no. 2, pp. 1093-1100, 2014.

[15] M. B. Amoghein, A. T. Tobeh, A. Gholipouri, S. J. Somarin, and M. Ghasemi, "Effect of cover crop in control of weed density and some qualitative and quantitative characteristics of sunflower," International Journal of Agriculture and Crop Sciences, vol. 5, no. 12, p. 1318.

[16] A. N. Komla, Effect of Organic Mulch on Growth and Yield of Sweet Pepper (Capsicum annuum L.), University of Ghana, 2013.

[17] A. Ramakrishna, M. T. Hoang, P. S. Wani, and T. D. Long, "Effect of mulch on soil temperature, moisture, weed infestation and yield of groundnut in northern Vietnam," Field Crops Research, vol. 95, no. 2, pp. 115-125, 2006.

[18] B. R. Aminu-Taiwo, A. A. Idowu, O. O. Alamu, O. W. Olaniyi, and O. O. Olufunmi, "Influence of mulch materials on population of plant parasitic nematode, growth and yield of okra (Abelmoschus esculentus L. Moench)," Journal of Agriculture and Veterinary Science, vol. 7, no. 4, pp. 12-17, 2014.

[19] T. J. A. Bruce, G. I. Aradottir, L. E. Smart et al., “The first crop plant genetically engineered to release an insect pheromone for defence," Scientific Reports, vol. 5, article 11183, 2015.

[20] D. R. Langham, "Phenology of sesame," in Issues in New Crops and New Uses, Janick and Whipkey, Eds., pp. 144-182, ASHS Press, Alexandria, VA, USA, 2007.

[21] R. T. da Silva, B. A. D. Oliveira, M. D. Fátima, D. M. A. Guimarães, and D. A. Sandro, "Physiological quality of sesame seeds produced from plants subjected to water stress," Revista Ciência Agronômica, vol. 47, no. 4, pp. 643-648, 2016.

[22] S. J. Van Donk, D. T. Lindgren, D. M. Schaaf, J. L. Petersen, and D. D. Tarkalson, "Wood chip mulch thickness effects on soil water, soil temperature, weed growth and landscape plant growth," Journal of Applied Horticulture, vol. 13, no. 2, pp. 9195, 2011.

[23] K. S. Kim, S. H. Park, and M. A. Jenks, "Changes in leaf cuticular waxes of sesame (Sesamum indicum L.) plants exposed to water deficit," Journal of Plant Physiology, vol. 164, no. 9, pp. 1134-1143, 2007.

[24] S. M. Masoud, "The effects of water deficit during growth stages of canola (Brassica napus L.)," American Eurasian Journal of Agricultural and Environmental Sciences, vol. 2, pp. 417-422, 2007.

[25] J. M. Adesina, K. O. Sanni, L. A. Afolabi, and A. F. Eleduma, "Effect of variable rate of poultry manure on the growth and yield of pepper (Capsicum annum) in south western Nigeria," Academia Arena, vol. 6, no. 1, pp. 9-13, 2014. 


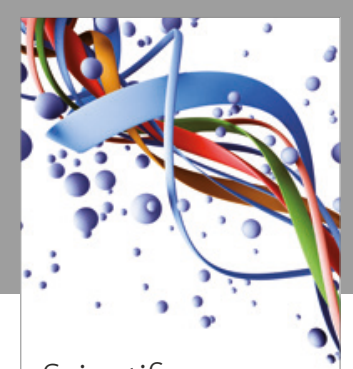

Scientifica
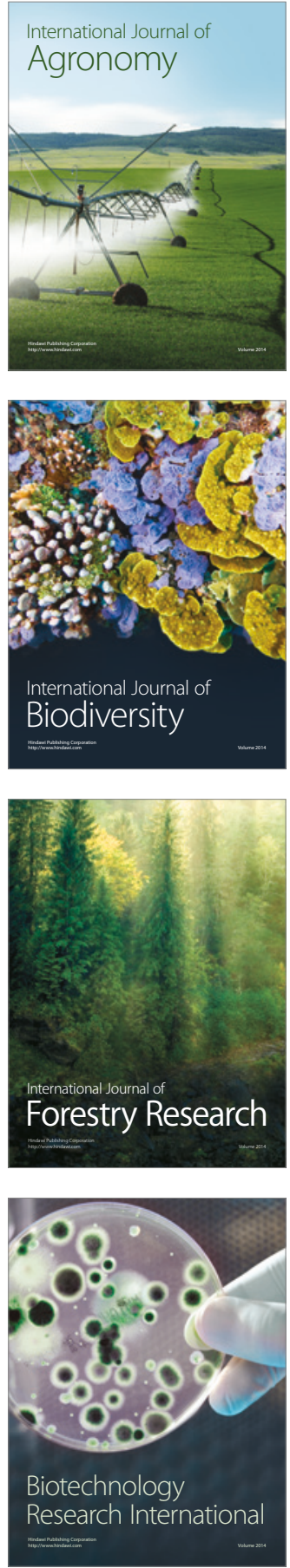
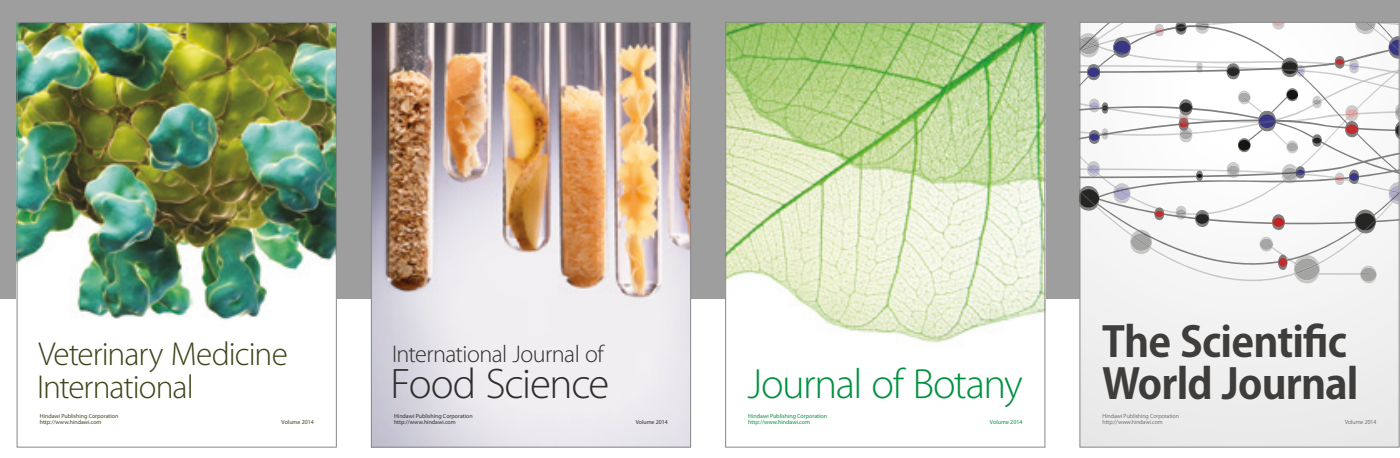

The Scientific

\section{World Journal}

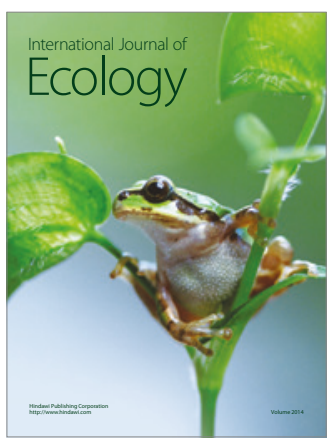

\section{Hindawi}

Submit your manuscripts at

https://www.hindawi.com
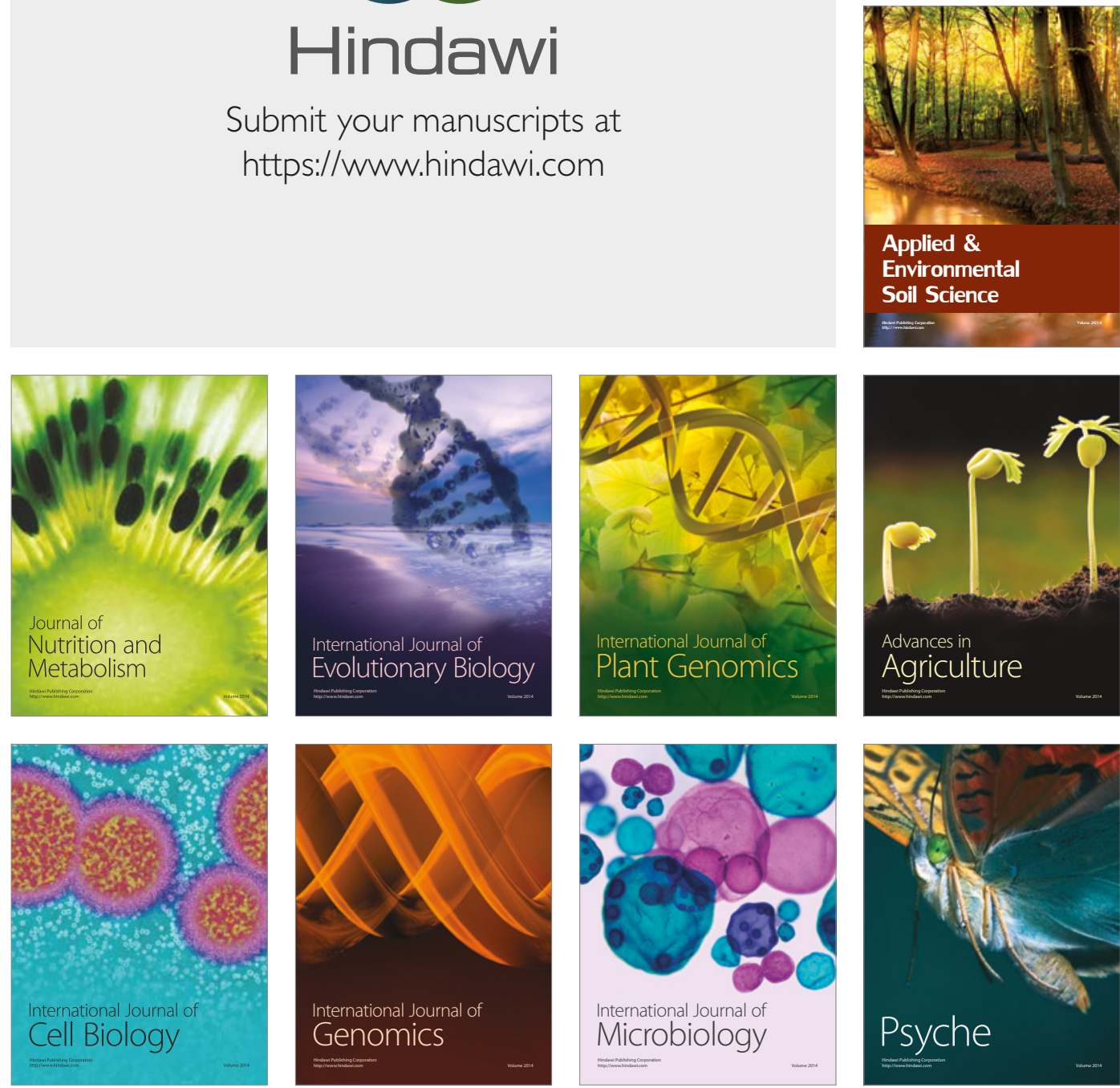

hternational Journal of Microbiology
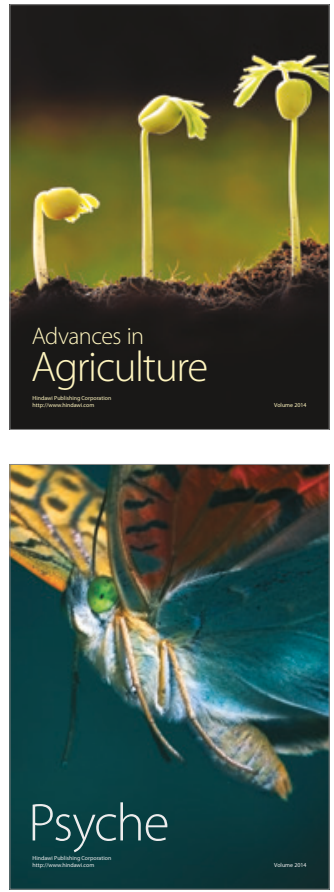